\title{
Liberating critical pedagogy of Paulo Freire in the scientific production of Nursing 1990-2017
}

\author{
Pedagogia crítica libertadora de Paulo Freire na produção científica da Enfermagem 1990-2017
}

La pedagogía crítica liberadora de Paulo Freire en la producción científica de la enfermería 1990-2017

\author{
Adriana Marcela Monroy Garzon', Kênia Lara da Silva', Rita de Cássia Marques' \\ ' Universidade Federal de Minas Gerais. Belo Horizonte, Minas Gerais, Brazil.
}

\begin{abstract}
How to cite this article:
Garzon AMM, Silva KL, Marques RC. Liberating critical pedagogy of Paulo Freire in the scientific production of Nursing 1990-2017. Rev Bras Enferm [Internet]. 2018;71(Suppl 4):1751-8. [Thematic issue:

Education and teaching in Nursing] DOI: http://dx.doi.org/10.1590/0034-7167-2017-0699
\end{abstract}

Submission: 10-06-2017 Approval: 01-28-2018

\begin{abstract}
Objective: To analyze the theoretical and methodological application of Paulo Freire's critical pedagogy in the scientific production of nursing. Method: An integrative review was carried out with consultation of the databases: LILACS, BDENF, MEDLINE, PUDMED and CINHAL. We included studies in the Spanish, English and Portuguese languages, published from 1990 to 2017. Results: A total of 38 articles were analyzed, of which the main concepts adopted were: dialogue/dialogicity, awareness/critical awareness and questioning. Regarding the application of the method, it was noticed the predominance of the adoption of elements such as culture circles, thematic phase and horizontality relation of the nurse with the individuals involved. Conclusion: Nursing has partially appropriated the Freire's referential. However, it reveals the intentionality of a transformative practice that requires deepening for the implementation of the method in its full.
\end{abstract}

Descriptors: Education Models; Teaching; Nursing Models; Education; Paulo Freire.

\section{RESUMO}

Objetivo: Analisar a aplicação teórica e metodológica da pedagogia crítica libertadora de Paulo Freire na produção científica da Enfermagem. Método: Realizou-se uma revisão integrativa com consulta às bases de dados: LILACS, BDENF, MEDLINE, PUDMED e CINHAL. Foram incluídos estudos nos idiomas espanhol, inglês e português, publicados desde 1990 até 2017 . Resultados: Foram analisados 38 artigos, dos quais apreendeu-se que os principais conceitos adotados do referencial foram: diálogo/dialogicidade, conscientização/consciência crítica e problematização. Em relação à aplicação do método, notou-se a predominância da adoção de elementos como: círculos de cultura, fase de tematização e relação de horizontalidade do enfermeiro com os sujeitos participantes. Conclusão: A Enfermagem tem se apropriado parcialmente do referencial freireano. Contudo, revela-se a intencionalidade de uma prática transformadora que exige aprofundamento para a implementação do método na sua integralidade.

Descritores: Modelos Educacionais; Ensino; Modelos de Enfermagem; Educação; Paulo Freire.

\section{RESUMEN}

Objetivo: Analizar la aplicación teórica y metodológica de la pedagogía crítica liberadora de Paulo Freire en la producción científica de la enfermería. Método: Se realizó una revisión integrativa con consulta a las bases de datos: LILACS, BDENF, MEDLINE, PUDMED y CINHAL. Se incluyeron estudios en Español, Inglés y Portugués, publicados desde 1990 hasta 2017. Resultados: Se analizaron 38 artículos, de los cuales se aprehendió que los principales conceptos adoptados del referencial fueron: el diálogo/la dialogicidad, la concientización/conciencia crítica y la problematización. En relación a la aplicación del método, se notó la predominancia de la adopción de elementos como: círculos de cultura, la fase de tematización y relación de horizontalidad del enfermero con los sujetos participantes. Conclusión: La enfermería se ha apropiado parcialmente del referencial de Freire. Sin embargo, se revela la intencionalidad de una práctica transformadora que requiere profundización para la implementación del método en su totalidad.

Descriptores: Modelos Educativos; La Enseñanza; Modelos de Enfermería; La Educación; Paulo Freire.

\section{CORRESPONDING AUTHOR Kênia Lara da Silva E-mail: kenialara17@gmail.com}




\section{INTRODUCTION}

The liberating critical pedagogy of Paulo Freire has been a guiding for educational practices in health. Its importance in this area is based on theoretical and methodological benchmarks that promulgated a vision and a shared building with all the actors involved in the implementation of culturally sensitive and appropriate practices to uniqueness in several contexts ${ }^{(1)}$.

This pedagogical proposal indicates a change in the traditional paradigm of education in health in relation to content and information transfer to a more critical and creative level. So, considering education as a guiding axis in the practice of nursing, critical pedagogy makes health care on unification of elements such as culture, enhancement of knowledge and recognition of the human being as an unfinished capacity to reinvent, in search of your own history ${ }^{(2)}$. In the process of construction, the Nursing Professional must adopt an attitude of respect and commitment to each other, generating a horizontal relationship manifested in reciprocal expertise and knowledge.

We recognize that there are several studies that announce the implementation of theoretical and methodological concepts of critical pedagogy of Paulo Freire in the educational practice of nursing. Seeking to deepen expertise and knowledge about this benchmark, which demarcates the methodological and theoretical research project called "Educação para a sexualidade dos adolescentes no contexto rural" (Education for sexuality of adolescents in the rural context), this integrative review was carried out.

It is assumed that theoretical appropriation of the methodological referential of Paulo Freire happens in different studies of nursing, that occur in various contexts and situations and actions that promote people's autonomy with regard to decision-making, with participation based on critical and reflective dialogue, in order to generate changes in the reality of individuals and their communities.

\section{OBJECTIVE}

To analyze the theoretical and methodological application of the liberating critical pedagogy of Paulo Freire in the scientific production of nursing.

\section{METHOD}

It is an integrative review that, according to Botelho, Cunha and Macedo $^{(3)}$, incorporates several concepts, opinions and research methods that enable synthesis of information and knowledge. Its extended approach leads to a depth about the available knowledge on the individual, the concept or theory.

The integrative reviews are performed in 6 steps: drafting of the guiding question of research and objective, the preparation of criteria for inclusion/exclusion of studies, search and selection of the studies in the databases, systematic analysis of data, discussion and interpretation of results by building a synthesis of the review.

This study was carried out in two periods: the first from July to December 2016, in which were collected primary data of this research; the second, in August of the year 2017, in which was held the update of the data found.
The guiding question of this research was: "How has the use of Paulo Freire's critical pedagogy for the scientific production of nursing been used?". For the refinement of the search, were defined the following inclusion criteria: studies and publications that were developed by nursing, studies involving concepts or the implementation of the methodological referential, studies published in the period of 1990 until 2017, studies in Spanish, English or Portuguese, studies published in peer reviewed journals, with availability and accessibility to the full document in the selected databases.

To search articles, were selected the journal portal VHL and CAPES portal and included the databases LILACS, MEDLINE, PUBMED, and CINHAL BDENF with the following descriptors: Educational Models/Modelos Educacionales/Modelos Educacionais, Teaching/Enseñanza/Ensino, Models Nursing/Modelos de Enfermería/Modelos de Enfermagem, Education/Educación/ Educação. We decided also to include "Paulo Freire" as free term in the title, abstract or subject. As a result, 148 articles were found. As a result, 148 articles were found. After a first floating reading, 34 articles were eliminated by abstracts and titles because they were not relevant to this research proposal. Shortly after the second review, a further 50 articles were excluded because they were repeated. After completing this phase, 64 studies were selected: 44 primary studies, 9 experience reports and 11 reflection articles.

A second filter was used to perform the critical reading of primary studies. For this purpose, was selected the tool of critical reading $(C A S P e)$ which is recommended for qualitative studies ${ }^{(4)}$. The tool consists of a set of questions you have three possibilities to answer: Yes, I do not know and no. In order to obtain a quantitative assessment parameter, values are assigned to the answers, namely: 2 points for yes, 1 point for I do not know or partially and zero for no. After the tool was applied, 31 primary studies were eliminated because they did not respond positively to the tool elimination questions or did not reach a score higher than 15 points. However, in the update carried out in August 2017, 5 articles were added that met the inclusion criteria and answered the review question, resulting in 38 articles in the final sample.

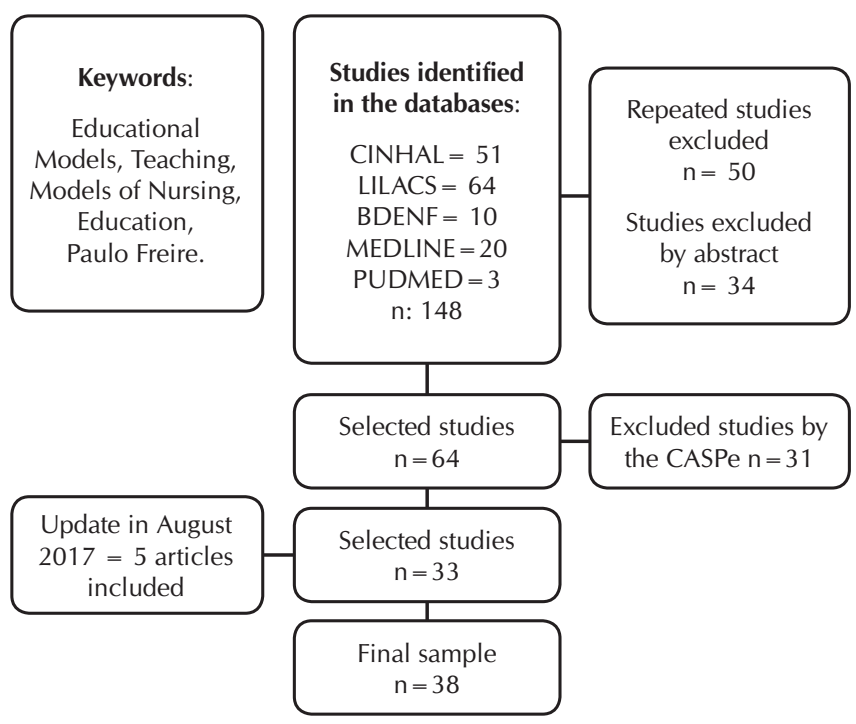

Figure 1 - Process of articles selection 
The texts included in the final sample were analyzed according to their evidence level $(E L)^{(5)}$ and classified into: level I - result of meta-analysis, of controlled clinical studies and with randomization; level II - evidence obtained in an experimental design study; level III - evidence obtained from quasi-experimental research; level IV - evidences obtained from descriptive studies or with a qualitative methodological approach; level V - evidence obtained from case reports or experience reports; level VI - evidence based on expert opinions or on the basis of standards or legislation.

\section{RESULTS}

We analyzed 38 articles, according to the objective proposed in this review. The distribution among the databases of the articles found was: CINHAL (50\%), LILACS (42.1\%), BDENF $(5.8 \%)$, MEDLINE (2.6\%). The articles were published in the period from 1997 to 2017, with a greater predominance in the years 2009 (7.6\%), $2012(17.9 \%), 2013(12.8 \%)$, and 2017 (7.6\%).

Regarding the evidence level, 16 qualitative studies (41\%) were in the stratum of evidence IV. At the evidence level $\mathrm{V}$ were 11 reports of experiences, 11 articles of reflection and 1 review article, representing $56.4 \%$ of the sample in this stratum. The publications revealed diverse objectives and experiences, with a predominance related to the development of educational programs and actions, as well as educational tools $\mathrm{s}^{(6-12)}$.

The analysis of the articles indicated that the Freire's referential was used in five areas: Teaching ${ }^{(13-15)}$, Health Promotion ${ }^{(16-18)}$, Primary Care(10,19), Care/Hospital(11,20-21), Prevention of Diseases and Injuries ${ }^{(7,12)}$. The settings chosen for the implementation of actions using this referential were: the Family Health Strategy ${ }^{(9,17)}$, undergraduate and graduation courses in Nursing ${ }^{(13,22-24)}$, the school context $^{(7,16,25)}$, community contexts ${ }^{(12,26-27)}$, outpatient units, hospitalization and surgical units ${ }^{(11,27-30)}$, and virtual contexts ${ }^{(31)}$. Regarding the themes addressed, there were predominance of those related to humanistic training, leadership, educational project, curriculum and transdisciplinarity ${ }^{(22,31)}$. Subjects that addressed sexual health and sexuality ${ }^{(9,12,19,32)}$, women's health such as breast cancer, cervical cancer and breast lymphedema were also identified ${ }^{(7,22)}$. We have also identified studies related to chronic diseases such as diabetes and kidney diseases ${ }^{(10,21,33)}$, child health such as breastfeeding and newborn care ${ }^{(29-30)}$, and health of the elderly in the hospital setting ${ }^{(11,34)}$

The analysis of selected articles was oriented by the following dimensions: theoretical appropriation and appropriation as methodological reference.

\section{The appropriation as theoretical reference}

The concepts most inserted in the development of nursing publications with the Freire's referential were: dialogue/dialogicity, awareness/critical awareness, questioning education/ questioning, humanization and autonomy. However, other concepts such as social practice, humanization, freedom/liberation and emancipation were present, as shown in Chart 1.

Dialogue was considered as one of the core concepts of Freire's liberating critical pedagogy and has been adopted in the publications from a expertise-sharing perspective, as well as in the sharing of knowledge and in the exchange of experiences among the

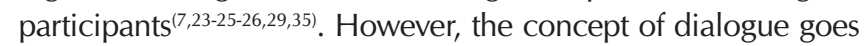

beyond the exchange of experiences and knowledge and does not occur in a single moment of the Freire's course. For Freire ${ }^{(41)}$, the true dialogue is transversal and involves fundamental characteristics such as humility, faith, hope and respect for the differences that are present throughout the process of investigation, thematization and critical unveiling so that the word becomes a liberating and humanized social practice.

Chart 1 - Concepts of the Paulo Freire Method adopted in the studies analyzed, 1990-2017

\begin{tabular}{|c|}
\hline Main concepts addressed in the publications \\
\hline dialogue/dialogicity ${ }^{(7,11-14,16,18,20,22-23,26,28-29,31-33,35-37)}$ \\
\hline awareness/critical awareness $s^{(8,14,16,19,21,33-35)}$ \\
\hline questioning education/ questioning ${ }^{(11,19,25,38)}$ \\
\hline autonomy ${ }^{(28,39-40)}$ \\
\hline freedom/liberation/liberating education $(23,36,38)$ \\
\hline culture circles $^{(13,16-17)}$ \\
\hline empowerment $^{(12,25)}$ \\
\hline emancipation/ emancipatory principles ${ }^{(15,40)}$ \\
\hline bank education ${ }^{(23-24)}$ \\
\hline humanization $^{(29)}$ \\
\hline dodiscência ${ }^{(39)}$ \\
\hline commitment $^{(14)}$ \\
\hline opression/opressed $^{(38)}$ \\
\hline
\end{tabular}

Awareness is also part of the structure of Freire's educational practice and is taken in the direction of questioning education. In the selected publications, the concept was interpreted as the act of reflecting, in depth, reality and problems ${ }^{(14,19,33)}$. The appropriation of this concept occurs through the discussion and differentiation between naive, transitive and critical consciousness $^{(34-35)}$. It is important to recognize that awareness goes beyond awareness, because it involves the individual's commitment to reality, its history and the possibility of transforming $\mathrm{it}^{(2,42-43)}$.

The term questioning was adopted as a transforming action of reality in a constant movement of critical unveiling of experience, situation and problems experienced ${ }^{(11,29)}$. It was adopted with a sense in the pedagogical field of overcoming alienating intellectualism ${ }^{(25)}$. However, few studies have associated the concept of questioning with the methodological proposal, revealing a gap in the theoretical-methodological implementation of the referential. The association should be evident in the development of the third phase of the method when applied to studies developed by Nursing.

Freedom/Liberation was interpreted in the publications as an achievement and as a result or end of a reflexive critical pedagogy in situations and power relations that were permeated by restrictions related to nursing practice ${ }^{(38)}$. Moreover, the word freedom was intimately associated with the liberating pedagogy that involves overcoming hierarchical relationships between the 
professor and the student. Under this interpretation, the concept was more used in the Nursing teaching area and discussed the relationship between the professor and the student in the development of the subjects, pedagogical projects and training experiences of critical, reflexive and human Nursing professional ${ }^{(23)}$.

It also reveals a limited interpretation between the concepts of freedom/liberation, because for Paulo Freire, the vision of freedom in this pedagogy has a prominent position, in which it is the matrix that gives meaning to an educational practice that only reaches effectiveness and efficacy to the extent that there is free and critical participation of students. "Freedom is an achievement, not a gift, it requires a permanent search. Permanent search that exists only in the responsible act of those who do it"(41).

The culture circles presented a connotation of collective space in which links were built between the participants, in order to discuss their reality and exchange experiences ${ }^{(13,16-17)}$. In this perspective, Paulo Freire recommends that, in the process of constructing circles, it is fundamental to understand the concept of culture as "the set of meanings and representations of a way of living confronted with other ways of living"(43).

The authors of the articles analyzed associate the term humanization with the policy of humanized health care. In the analyzed publications, it was interpreted as appreciation of culture, respect and expression of the individuals' solidarity. It was also adopted as a result of critical and reflexive dialogic educational practice ${ }^{(29-30)}$. But from the Freire's perspective, humanization refers to human nature as an unfinished individual. In this sense, humanization is understood as an open, broad, flexible and hopeful process with the certainty that it can always be more.

It was evidenced that the use of the theoretical reference of Paulo Freire was linked to other theoretical references of Nursing, such as Dorothea Orem's Theory of self-care/supporteducation system and Madeleine Leininger's Theory of crosscultural care $^{(10,26,28,35)}$

Leininger's concept of care aims to understand the values, beliefs and habits of the individuals with whom the professional interacts, in order to preserve, accommodate and/or repatriate care. In this sense, this theory has partially converged with the concept of dialogue, in the commitment of the professional and the professor to know, to listen and to value the individual's culture.

The concept of self-care of Dorothea Orem, according to the publications, stood out as a practice of the person for itself and developed by it. The essence of self-care was related to self-control, freedom, responsibility of the individual and the search for improvement in their quality of life. Thus, it diverges from the collective, participatory and dialogic idea of the Freirie's principles, which describes that man does not liberate himself or learn alone, but always together.

\section{The appropriation as a methodological reference}

The use of the Freire's method as a methodological reference was identified in 20 publications that pointed out the implementation of the phases or elements of the method, as shown in Chart 2. Of these studies, only 8 publications adopted the Freire's itinerary (research, thematization and questioning), but with some modifications in the appointments. The rest of these publications adopted some element or phase of the method with a predominance of culture circles, the role of facilitator and empathy of the professor ${ }^{(9,26)}$, keywords and generating themes ${ }^{(25,38)}$, as well as the citation of the horizontal and dialogic relationship/dialogue $\mathrm{e}^{(9,28,30)}$.

Chart 2 - Phases of the Freire's methodology adopted in the studies analyzed

\begin{tabular}{|l|}
\hline Implementation of the Freire's itinerary \\
\hline Investigation phase ${ }^{(12,16-17,19-21,33)}$ \\
\hline Thematization phase $^{(6,16-17,19-21,25,31,33)}$ \\
\hline Questioning phase ${ }^{(6,12,17,19-21,27,31)}$ \\
\hline All the phases of the method \\
\hline Some element of the method $^{(17,9-10,22,24,26,28,30,39)}$ \\
\hline
\end{tabular}

With regard to the implementation of the research phase, the studies described regarding the commitment of educating to meet the thought, language and perception of reality of the individual, that is, knowing how were relations of the individual with the world and how they acted in your reality ${ }^{(41)}$. However, it is known that, in the development of this phase, there is a need of time available in order to make an immersion in the daily life and culture of the individuals and their communities.

In the analysis of the articles, there were very few studies that implemented the investigation phase according to the reference, describing the time invested. Publications were found to have developed this phase in just a moment, through discussion circles, face-to-face interviews and surveys ${ }^{(17,19)}$, using various techniques such as, for example, the participant observation and the wheels of conversation ${ }^{(12,20-21,33)}$.

On the methodology of Paulo Freire, the research implies methods based on exchange that must be present from the start, building a relationship of empathy and solidarity between the students and the professor ${ }^{(41)}$.

The theme is preceded by the research stage, characterized by the implementation of the meanings of the reality of the situations and of the vocabulary universe. Thus, "the generating theme is substantive by generating words as it emerges from the personal and collective reflexivity about those words"(2).

In the analysis of the articles was found a small number of publications involving the individuals participating in the analysis and discussion of the generating themes ${ }^{(25,44)}$. At that stage, was prevalent the use of semi-structured interview and the circles of conversation in data collection. However, the thematic analysis was developed by researchers without the involvement of the participants ${ }^{(19,22,33)}$. In another study, a survey of the issues occurred generators by participant observation, but there was no dialogue with the participants about the work universe identified to define these themes ${ }^{(21)}$.

At the stage of questioning the unveiling critical, process by which individuals overcome magic vision and develop a critical view of your reality. According to Freire's perspective, this is the time to understand the development of critical consciousness about the generating themes ${ }^{(2)}$

The articles just describe how they developed the discussion groups or culture circles and as complementary techniques 
were used for heating and the motivation of the participants without showing if there have been changes in reality or as These occurred. On the other hand, some publications have reported the perceived changes in participants and in the process throughout the development of crop circles, such as: attitude of dialogue, horizontal relations between the health professional and the user, feelings of security in the exchange of experiences and knowledge ${ }^{(12,17,19)}$, as well as the acquisition of scientific knowledge about a disease and/or treatment ${ }^{(21)}$.

\section{DISCUSSION}

The theoretical and methodological analysis showed that the adoption of the reference system on the experiences of nursing has prevalence in the adult population, in order to understand meanings and perceptions of educational experiences and actions implemented. The evidence level on the subject of health education and the implementation of the benchmark is down. As to the quality, note the existence of weaknesses in the description of the phases of the method adopted, which limited the referential methodological analysis using just a few concepts of Freire. That demonstrated the need to invest in the methodological rigor nursing of reference used. The review also demonstrated that pragmatism and activism have distorted the methodological referential bases on educational practice of nursing.

According to Second Favero ${ }^{(42)}$, there is a limitation in the discussion of the concept of individual to be unfinished, what makes a pragmatic educational proposal of reduction by Freire, because it requires a commitment of the professor as a individual that is part of a reality and not just as a spectator. In this posture, the nurse, as individual of a social educational practice in health, also have to take ownership of this methodological rigor that goes beyond preparing theoretically looking for information and updates on a specific theme. He need to modify your posture in order to commit to meet and enhance the experiences of health of individual within the educational Practice ${ }^{(6)}$.

The methodological rigor that proposes the critical education and problem of Paulo Freire is one that requires a professional development about the realities and social perspectives of political and economic subjects. To achieve this goal, it is essential to develop and involved, since the first stage of research, the individuals participating in the process. This requires commitment, willingness and openness to do a cultural immersion and requires time to learn about the daily lives and relationships of the individual, because it is from the cultural immersion that goes gradually phases of the method. This way, it is understood that the method should be continuous and persistent, aiming at transforming actions of the individuals involved. With this, it is considered that the findings showed limitations in publications analyzed.

Another challenge in the appropriation of the Freire's methodological referential is the distance between conditions for the discovery of the themes under Paulo Freire's design generators since "the thematic universe cannot be prefixed, prescribed by scripts or by researchers as exclusive research individuals"(41). According to Barrow ${ }^{(43)}$, binds the change to a practice that is built collectively within the crop circles. Thus, it is recommended to overcome the educational processes in which the nursing professionals bring ready content and put the issues without involving the individual, patient or user in your construction. According to this author, the model breaks with the principle of hope, because the man can and should change the world with your intelligence and your action.

The adoption of the concept of dialogue and awareness if reaffirmed as the Foundation of the educational practice of nursing based on Freire's reference, because the man is done in silence, but in words. Shows a concern to reflect since the Academy about the dialogue as the educational practice of nursing in order to turn the challenge of vertical relations, of power and imposition in a more humanistic practice and as one of the main contributions theory for nursing ${ }^{(44)}$.

The dialogue is a central element in Freire's attitude, since the hermeneutic perspective that protects the ability of individuals in the pursuit of argumentative knowledge and your view of reality. In this sense, the democratization of communication because, in dialogue, acknowledged the heterogeneity of reality and the learning collaborative, inclusive and that it gives all the conditions to express themselves. Furthermore, the dialogue represents the opening to interculturality and pluralism of knowledge and visions, reducing the distance between the individual ${ }^{(45)}$.

Critical reflective dialogue releases and, with that, the man learns to say your Word. It is understood that the dialogue is a transversal concept at all stages in the method Paulo Freire and should become a social practice as one of the fundamental conditions for this to occur with the commitment and the respectful curiosity of the professor to meet and experience the culture, knowledge and reality of the people. Thus, the dialogue holds Freire's theory from research methodology, the recognition of words and generating themes that allow you to unveil the needs of the community and the students. In addition, the dialogue, from the perspective of critical theory and social, is part of the nature of human beings as social process of collective reflection defendant in educational practice.

In general, there is a gap between theoretical appropriation of the concepts of dialogue, culture circle, awareness and its application in nursing educational practice. One should pay attention to these concepts underlie a pedagogy in which the condition sine qua non is the participation of the students and the coherence of the Nursing Professional, guiding your educational practice by the desires and expectations of the individual, of families and communities in a democratic process and humanized.

Another condition for the critical dialogue as social practice is the collective dimension, that is, "it is impossible to pronounce the world alone in the same way that become subject when section of the other"(46). However, the studies used individual approach methods, such as semi-structured individual interviews, and surveys to developing the dialogue between the health professional and the individual participants of educational practices. It is, thus, the need to discuss the theoretical and methodological coherence in the appropriation of the benchmark of Paulo Freire. It is understood that the reduction in research phase to a single moment can limit the discovery of vocabulary and thematic universe diverging from the methodological proposal of Paulo Freire.

In articles analyzed, the transformation of reality was revealed from the point of view of perceived changes in the subject 
or in the internal relations of the educational process. These changes are positive; however, insufficient to say that reached the assumption of critical pedagogy of Paulo Freire, which is the promotion of awareness and the release to manufacturing. In this way, there is a simplification of the expected results from the Freire's benchmark.

\section{Limitations of the study}

The limitations of the study refer to the definition of the time for the review and the evidence level of the texts found. Regarding the first item, it is believed that this has not interfered in the composition of the sample, since the publications have been dated from 1997. As regards the second item, there was a concentration of the texts found in the evidence levels IV and V, which indicates that the Freire's theoretical-methodological referential has been adopted in the literature of a qualitative approach and reports of experience, with little production of hard evidence.

\section{Contributions to the sectors of nursing, health or public policy}

We point out that the findings highlighted in this review bring contributions to the field of nursing, health or public policy arising in the context of care and health promotion with a practice that lies in the deconstruction of hierarchical relationships in the field of scientific knowledge about the knowledge of the user or patient. Nursing can and should build an educational process that positions, health patient, user, families and communities as social individuals that have knowledge and experience that should be valued ${ }^{(47)}$ and, with that, there is what is essential to adapt the scientific knowledge to the cultural, geographical and historical contexts of individuals.

\section{FINAL CONSIDERATIONS}

Nursing has appropriate partially from Freire's reference in various contexts and perspectives from the field of hospital health promotion and academic. This reflects the magnitude of the concepts and your flexibility in the construction of a settlement process over time and your creative possibilities in the pragmatic context of nursing.

The findings indicate the adoption of some elements of the Paulo Freire's method with higher expression of the concepts of dialogue/Exchange, awareness/critical conscience. In relation to the phases of the methodology, there was predominance in adoption of elements, like the crop circles, the posture of horizontality and respect at the time of the exchange of experiences and knowledge. However, there were differences between the techniques and methods implemented in studies and methodological proposal of Paulo Freire.

It is concluded that there is a partial appropriation of the Paulo Freire referential with weaknesses and limits on theoretical and methodological application of concepts and stages proposed by author in nursing studies. So, even if you can highlight the conceptual and practical approach, the simplification of the liberating Paulo Freire's critical pedagogy in nursing scientific production.

However, it is the intent and the objectives of a transformative practice of reality which requires, to your full and critical appropriation, a deepening understanding of the concepts and the preservation of the principles and key elements for the implementation of the method in its full as a collective construction in educational practice in nursing.

\section{REFERENCES}

1. Barry MM, Battel-Kirk B, Davison H, Dempsey C, Parish R, Schipperen M, et al. The CompHP Project Handbooks [Internet]. Paris: IUHPE; 2012. [cited 2016 Jun 11]. 103 p. Available from: https://www.fundadeps.org/recursos/documentos/450/CompHP Project_Handbooks.pdf

2. Streck DR, Redin E, Zitkoski JJ. Diccionario Paulo Freire. 2 edição. Belo Horizonte; 2010. p. 221-222.

3. Acunha PLP. Manual Revisão sistemática integrativa: a pesquisa baseada em evidências [Internet]. 2014 [cited 2017 Mar 14]. 38p. Available from: http://disciplinas.nucleoead.com.br/pdf/anima_tcc/gerais/manuais/manual_revisao.pdf

4. Critical Appraisal Skills Programme Español[Internet]. 2013 [cited 2016 Apr 10]. Available from: http:/www.redcaspe.org/ herramientas/instrumentos

5. Souza MT, Dias M, Carvalho R. Integrative review: what is it? how to do it? Einsten[Internet]. 2010 [cited 2016 Sep 15];8(1):102-6. Available from: http://www.scielo.br/pdf/eins/v8n1/1679-4508-eins-8-1-0102.pdf

6. Hermida PMV, Marçal CCB, Ebsen ES, Heidemann ITSB, Meirelles BHS. Health education in the practices of the health professional subsystem. Rev Baiana Enferm[Internet]. 2016[cited 2016 Sep 15];30(2):1-12. Available from: https://portalseer.ufba.br/index.php/ enfermagem/article/view/15726/pdf_54

7. Valente CA, Andrade V, Soares MBO, Silva SR. Atividades educativas no controle do câncer de colo do útero: relato de experiência. Rev Enferm Cent O Min[Internet]. 2015[cited 2016 Sep 15];5(3):1898-904. Available from: http://www.seer.ufsj.edu.br/index.php/ recom/article/view/576

8. Canevera BP, Prado ML, Gomes DC, Jesus BH. Epistemological world awareness of healthcare faculty. Rev Gaúcha Enferm[Internet]. 2016[cited 2017 Mar 5];37(3):1-8. Available from: http://www.scielo.br/pdf/rgenf/v37n3/en_0102-6933-rgenf-1983-144720160353811.pdf

9. Souza MM, Brunini S, Almeida NAM, Munari DB. Educative program about sexuality and Sexually Transmitted Diseases: experience report with a group of adolescents. Rev Bras Enferm[Internet]. 2007[cited 2017 Mar 19];60(16):102-5. Available from: http://www. scielo.br/pdf/reben/v60n1/a20v60n1.pdf 
10. Coelho MS, Maria D, Vieira G, Silva D. Grupo educação-apoio: visualizando o autocuidado com os pés de pessoas com diabetes mellitus. Ciênc Cuid Saúde[Internet]. 2006 [cited 2017 Mar 19];5(1):11-5. Available from: http://eduem.uem.br/ojs/index.php/ CiencCuidSaude/article/view/5101/3321

11. Ferreira ML, Titonelli AN. Knowledge and experiences of caregivers for post-surgical respiratory complications in elderly people, shared with the nurse. Esc Anna Nery Rev Enferm[Internet]. 2012[cited 2017 Mar 14];16(3):553-60. Available from: http://www. scielo.br/pdf/ean/v16n3/18.pdf

12. McQuiston C, Choi-Hevel S, Clawson M. Protegiendo Nuestra Comunidad: empowerment participatory education for HIV prevention. J Transcult Nurs[Internet]. 2001[cited 2017 Mar 14];12(4):275-83. Available from: http://journals.sagepub.com.ez27. periodicos.capes.gov.br/doi/pdf/10.1177/104365960101200402

13. Dalmolin IS, Faria LM, Perão OF, Nunes SFL, Meirelles BHS, Heidemann ITSB. Dialoguing with Freire in the Circle of Culture: a health promotion strategy. Rev Enferm UFPE[Internet]. 2016[cited 2017 Mar 14];10(1):185-90. Available from: http://www.revista. ufpe.br/revistaenfermagem/index.php/revista/article/view/8298/pdf_9382

14. Maia NMFS, Nunes BMVT, Moura MEB. Students' participation in the development of the pedagogical project in a Nursing program. Invest Educ Enferm[Internet]. 2013[cited 2017 Aug 1];31(2):183-90. Available from: http://www.scielo.org.co/pdf/iee/ v31n2/v31n2a03.pdf

15. Sharples N. An exploration of deaf women's access to mental health nurse education in the United Kingdom. Nurse Educ Today [Internet]. 2013 [cited 2017 Mar 14];33(9):976-80. Available from: https://www.ncbi.nlm.nih.gov/pubmed/23159007

16. Marques ADB, Branco JGO, Cavalcante JB, Santos LMD, Catrib AMF, Amorim RF. Research-action in the perspective of nursing in environmental education: from theory to practice. Rev Enferm UFPE[Internet]. 2016[cited 2017 Aug 1];10(3):1151-61. Available from: http://www.revista.ufpe.br/revistaenfermagem/index.php/revista/article/view/9076/pdf_9912

17. Alves LHS, Boehs AE, Heidemann ITSB. Family health strategy professionals and user's perception on health promotion groups. Texto Contexto Enferm [Internet]. 2012 [cited 2017 Mar 14];21(2):401-8. Available from: http://www.scielo.br/pdf/tce/v21n2/ en_a19v21n2.pdf

18. Alvim NAT, Ferreira MA. Problematizing perspective of popular education in health care and nursing. Texto Contexto Enferm[Internet]. 2007[cited 2017 Jun 5];16(2):315-9. Available from: http://www.scielo.br/pdf/tce/v16n2/a15v16n2.pdf

19. Denardi V, Baldissera A, Maria S, Bueno V, Akiko L, Hoga K. Improvement of older women's sexuality through emancipatory education. Health Care Women Int[Internet]. 2012 [cited 2017 Mar 14];33:956-72. Available from: https://www.ncbi.nlm.nih. gov/pubmed/22946596

20. Coscrato G, Bueno SMV. Concepts of health education by public health nurses. Rev Esc Enferm USP [Internet]. 2013 [cited 2017 Mar 14];47(3):707-13. Available from: http://www.scielo.br/pdf/reeusp/v47n3/en_0080-6234-reeusp-47-3-00714.pdf

21. Bernardi CC, Casagrande LDR. Paciente com insuficiencia renal cronica em tratamento hemodialitico: atividade educativa do enfermeiro. Rev Latino-Am Enferm[Internet]. 1998[cited 2017 Jun 20];6(4):31-40. Available from: http://www.scielo.br/pdf/rlae/ v6n4/13873.pdf

22. Panobianco MS, Souza VP, Prado MAS, Gozzo TO, Magalhães PAP, Almeida AM. Knowledge construction necessary for the development of a didactic-instructive manual for post mastectomy lymphedema prevention. Texto Contexto Enferm[Internet]. 2009 [cited 2017 Mar 15];18(3):418-26. Available from: http://www.scielo.br/pdf/tce/v18n3/a03v18n3.pdf

23. Amestoy SC, Backes VMS, Thofehrn MB, Martini JG, Meirelles BHS, Trindade LL. Nurses' perception of the teaching-learning process of leadership. Texto Contexto Enferm[Internet]. 2013 [cited 2017 Mar 13];22(2):468-75. Available from: http://www.scielo. $\mathrm{br} / \mathrm{pdf} / \mathrm{tce} / \mathrm{v} 22 \mathrm{n} 2 / \mathrm{v} 22 \mathrm{n} 2 \mathrm{a} 24 . \mathrm{pdf}$

24. Chagas MIO, Barroso MGT, Varela ZMV. Experiencing a socia-cultural approach in nursing education. Rev Bras Enferm[Internet] 2000[cited 2017 Jun 3];53(1):87-93. Available from: http://www.scielo.br/pdf/reben/v53n1/v53n1a11.pdf

25. Silveira EAA, Ribeiro JEO, Oliveira LA, Silva NA, Lima EHO. An experience of health education among nursing students and adolescents from PESCAR project. Rev Enferm Cent O Min [Internet]. 2017[cited 2017 Aug 17];7:1-7. Available from: http://www. seer.ufsj.edu.br/index.php/recom/article/view/1931

26. Portella MR. [Caring forahealthyaging: the construction of an educational process with rural women]. Rev Bras Enferm [Internet]. 1999[cited 2017 May 17];52(3):355-64. Available from: http://www.scielo.br/pdf/reben/v52n3/v52n3a05.pdf Portuguese

27. Connor AN, Ling CG, Tuttle J. Peer Education Project with Persons who have Experienced Homelessness. Public Health Nurs [Internet]. 1999 [cited 2017 Mar 19];16(5):367-73. Available from: http://onlinelibrary.wiley.com/doi/10.1046/j.1525-1446.1999.00367.x/pdf

28. Gonçalves LHT, Schier J. "Grupo aqui e agora": uma tecnologia leve de ação sócio-educativa de enfermagem. Texto Contexto Enferm [Internet]. 2005 [cited 2017 Mar 16];14(2):271-9. Available from: http://www.scielo.br/pdf/tce/v14n2/a16v14n2.pdf

29. Queiroz PP, Pontes CM. Meanings of educative nursing actions centred on breastfeeding from the perspective of breastfeeding mothers and their families. Referência [Internet]. 2012 [cited 2017 May 17]; serie III(8):95-103. Available from: http://www.scielo. mec.pt/pdf/ref/vserllln8/serllln8a10.pdf

30. Ferecini GM, Fonseca LMM, Leite AM, Daré MF, Assis CS, Scochi CGS. Perceptions of mothers of premature babies regarding their experience with a health educational program. Acta Paul Enferm [Internet]. 2009[cited 2017 Mar 15];22(3):250-6. Available 
from: http://www.scielo.br/pdf/ape/v22n3/en_a03v22n3.pdf

31. Labegalini CMG, Nogueira IS, Rodrigues DMMR, Almeida EC, Bueno SMV, Nogueiraa CMGLIS, et al. Educational action research on Facebook ${ }^{\circledR}$ : combining leisure and learning. Rev Gaúcha Enferm[Internet]. 2016[cited 2017 Mar 16];37:1-9. Available from: http://www.scielo.br/pdf/rgenf/v37nspe/en_0102-6933-rgenf-1983-14472016esp64267.pdf

32. Vidal CRPM, Miranda KCL, Pinheiro PNC, Rodrigues DP. [Climacteric women: a proposal for nursing clinical care based on Freirean ideas]. Rev Bras Enferm[Internet] 2012[cited 2017 Jun 5];65(4):680-4. Available from: http://www.scielo.br/pdf/reben/ v65n4/a19v65n4.pdf Portuguese

33. Tavares DMS, Rodrigues RAP. Education directed to raise the consciousness of elderly patients with diabetes: a nurses' intervention proposal. Rev Esc Enferm USP [Internet]. 2002 [cited 2017 Mar 16];36(1):88-96. Available from: http://www.scielo.br/pdf/reeusp/ v36n1/v36n1a12.pdf

34. Santiago RF, Luz MHBA. Health education practices for elderly caregivers: a look at nursing from Paulo Freire's perspective. Rev Min Enferm[Internet]. 2012 [cited 2017 Mar 19];16(1):136-42. Available from: http://www.revenf.bvs.br/pdf/reme/v16n1/19.pdf

35. Martins PAF, Alvim NAT. Shared Care Plan: convergence between the educational problematizing perspective and the Theory of Nursing Cultural Care. Rev Bras Enferm [Internet]. 2012 [cited 2017 Mar 16];65(2):368-73. Available from: http://www.scielo.br/ pdf/reben/v65n2/v65n2a25.pdf

36. Lima KMC, Teixeira MGB. Freire's contribution to the practice and critical education. Rev Latino-Am Enferm[Internet]. 2004[cited 2017 Mar 19];12(4):631-5. Available from: http://www.scielo.br/pdf/rlae/v12n4/v12n4a08.pdf

37. Ferreira MVF, Godoy S, Góes FSN, Rossini FP, Andrade D. Lights, camera and action in the implementation of central venous catheter dressing. Rev Latino-Am Enferm[Internet]. 2015[cited 2017 Mar 5];23(6):1181-6. Available from: http://www.scielo.br/ pdf/rlae/v23n6/0104-1169-rlae-23-06-01181.pdf

38. Mooney M, Nolan L. A critique of Freire's perspective on critical social theory in nursing education. Nurse Educ Today [Internet]. 2006 [cited 2017 Mar 5];26(3):240-4. Available from: https://www.ncbi.nlm.nih.gov/pubmed/16330133

39. Silva CRLD, Keim EJ, Bertoncini JH. [Interdisciplinary teaching for health: planning nurse undergraduate programs]. Rev Bras Enferm[Internet]. 2003[cited 2017 Jun 7];56(4):424-8. Available from: http://www.scielo.br/pdf/reben/v56n4/a25v56n4.pdf

40. Salci MA, Maceno P, Rozza SG, Silva DMGV, Boehs AE, Heidemann ITSB. Health education and its theoretical perspectives: a few reflections. Texto Contexto Enferm[Internet]. 2013 [cited 2017 Mar 19];22(1):224-30. Available from: http://www.scielo.br/ pdf/tce/v22n1/27.pdf

41. Freire P. Pedagogía do oprimido [Internet]. 1970[cited 2017 Mar 19]. 175 p. Available from: http://lahistoriadeldia.wordpress. com/2010/04/06/paulo-freire-pedagogia-del-oprimido-descargar-libro/

42. Favero O. O legado de Paulo Freire: passado ou atualidade. Rev Educ Jovens Adultos [Internet]. 2007 [cited 2017 Aug 1];1(0):39-44. Available from: http://www.usfx.bo/nueva/vicerrectorado/citas/SOCIALES_8/Pedagogia/78.pdf

43. Brandão CR. O que é método Paulo Freire. 19. ed. São Paulo: Brasiliense, 1994. 113p.

44. Heidemann IBS, Boehs AE, Wosny AM, Stulp KP. Theoretical, conceptual and methodological incorporation of the educator Paulo Freire in research. Rev Bras Enferm[Internet] 2010 [cited 2017 Aug 1];63(10):416-20. Available from: http://www.redalyc. org/pdf/2670/267019593011.pdf

45. Hidalgo C. Hermenéutica y Argumentación: aportes para la comprensión del diálogo intercultural. Estud Filos [Internet]. 2016[cited 2017 Sep 30];54:107-30. Available from: http://www.scielo.org.co/pdf/ef/n54/0121-3628-ef-54-00107.pdf

46. Pitano SDC. A educação problematizadora de Paulo Freire, uma pedagogia do sujeito social. Rev Inter Ação [Internet]. 2017[cited 2017 Aug 1];42(1):87. Available from: https://www.revistas.ufg.br/interacao/article/view/43774

47. Brasil. Ministério da Saúde. Secretaria de Gestão Estratégica. Politica Nacional de Educação Popular em Saúde[Internet] 2012 [cited 2017 Sep 30]. 26p. Available from: http://www.crpsp.org.br/diverpsi/arquivos/PNEPS-2012.PDF 